have done much to fulfil his steadfast purpose of securing the Society's continuation, as its Charter requires, in perpetuity. After retirement from active Council work, he was elected an Honorary Vice-President of the Society, a distinction visitors to Osborne tell us gave him much pleasure. He most generously presented an important selection of his books to the Library, substantially strengthening its representation on South-East Asia. Dennis will be greatly missed at the Society, to which his contribution over more than twenty-one years has been so impressive.

A. D. H. Bivar

\title{
FRANK STEELE, OBE
}

\section{February II I923 to November 201997}

Frank Steele, after a successful career as an intelligence officer, made an effective transition to merchant banking at the age of 52 . He gave further evidence of his versatility in his voluntary work for the Royal Asiatic Society and for the Royal Society of Asian Affairs.

Frank Fenwick Steele came from a family with a tradition, over several generations, of service in India. He was, however, educated in this country, first at St Peter's School, York and after at Emmanuel College Cambridge where he read mechanical engineering. It was natural, therefore, that in 1943 he was commissioned into REME in which he served until 1947, mainly in India and South-East Asia. On leaving the Army he joined the Colonial Service and served in Uganda between I948-1950.

In I95I he joined SIS by the unusual method of placing an advertisement in the press, detailing his qualifications. Soon after joining, he was posted to Basra, at the time when active planning was taking place for the invasion of southern Iran after the temporary expulsion of the Shah and the nationalization of BP's interests. The invasion, fortunately, did not take place. But Steele's contribution to its planning marked him out early as an officer of exceptional ability.

Service in Cyprus, Libya and London followed, in the course of which he won considerable respect from his colleagues and was identified as a "flier". In the late I95os he served in Beirut, returning to London in $196 \mathrm{I}$. In I965 he was posted to Amman and 1968 to Nairobi. In 197I he went to Northern Ireland as a member of the small FCO team there, and in May of the following year succeeded to its senior position. This intensely political post, in a rapidly changing situation, suited Steele's talents and temperament well and further enhanced his reputation. In 1973 he returned to a senior position connected with the Middle East in London, but he took premature retirement in 1975, frustrated by the constraints placed upon his freedom of action. After leaving the FCO in 1975, Frank Steele joined Kleinwort Benson Limited, the merchant bank, first as a consultant on Middle East matters and then as a director in charge of the bank's not inconsiderable export financing activities. He retired in 1987.

Working at Kleinworts gave him the opportunity to use, in a commercial context, his characteristic tenacity, persuasiveness and thoroughness. He made many friendships with both clients and colleagues and became, within a short space of time, a true banker. 
Frank Steele was President of the Royal Asiatic Society from 1988-90. He came to the Society as a gust of fresh air. He launched a major survey asking fellows how the Society should go forward in future. Many of the new policies of the Society in the r 990 os are to a greater or lesser extent the outcome of the survey: the Society's support for a wider range of academic activity, its new publishing policies in collaboration with publishing houses, and its substantial focus on conserving its treasures. It is thanks to Frank Steele that, in the opinion of the Society's conservator Graeme Gardiner, the Society is substantially in advance of a good number of other learned societies, not to mention Oxford and Cambridge colleges, in caring for its treasures.

Much of the above is taken from The Times of the $26^{\text {th }}$ November 1997

Francis Robinson 